\title{
The Language of Revolution and the Power of Storytelling in The Pregnant Widow
}

\author{
Alaa Alghamdi \\ Department of Languages \& Translation \\ Taibah University, Medina, Saudi Arabia \\ E-mail: alaaghamdi@yahoo.com
}

Received: 20-08-2013

doi:10.7575/aiac.ijalel.v.3n.1p.72
Accepted: 10-10-2013

Published: 01-01-2014

\begin{abstract}
Martin Amis uses the language of revolution to describe the newly altered social circumstances at the height of the sexual revolution in his semi-autobiographical novel The Pregnant Widow. The concept of a 'language of revolution' as well as second- and third-wave feminist scholarship is applied to a textual analysis of the novel. Amis's brand of satire creates a sense of displacement and challenges existing perceptions about gender, culture and sexuality, exposing them as constructed and changeable norms. Moreover, it becomes clear that the author is skeptical about the benefits of the sexual revolution for either gender, and that he views its liberating aspects as unfulfilled, particularly for women. Given that Amis names one of his characters Scheherazade, evoking the legendary heroine of The Arabian Nights, the importance of storytelling in the novel is also examined and found to be a potentially redeeming force.
\end{abstract}

Keywords: Martin Amis, sexual revolution, feminism, satire, gender, revolution

\section{Introduction}

In his 2010 semi-autobiographical novel The Pregnant Widow, Amis recaptures the sense of newness and the abrupt shift in society that came about as the result of the sexual revolution by using what is, indeed, the language of revolution in the political sense. As the author is an exceptionally accomplished humorist and incisive social commentator, it will come as no surprise that this work is no nostalgic ode to the liberation of the self but a complex analysis, its amusing storyline leading us further into a contemplation of sexual politics. What $i s$ surprising, however, is the germ of optimism that exists at the heart of this fundamentally desultory account. At some level it seems the author is still waiting for the revolution to fulfill itself. His nostalgic account of the summer adventures of his youthful protagonist Keith is therefore both confessional and analytical, righting the wrong that occurs when we take amorous matters too lightly. As in other work, Amis's primary tool is satire - his own brand, in which he subtly shifts the frame within we view events, rendering them still familiar but indisputably altered.

\section{Research Focus and Methodology}

Particularly in its early stages, as the scene is being set, Amis's narrative is shot through with the use of language perhaps more suitable for political revolution, either real or fictional. One is reminded, for example, of Margaret Atwood's The Handmaid's Tale, with its ample references to the contrast between a familiar past and a radically changed, dystopian present. At the same time, a historical account of the communist revolution in China or indeed the French Revolution would capture this same awareness of a sharp dividing line between past and present, with dangers lurking in the present as new standards must be quickly adapted. These new standards are fact, but still require constant, cautious reminders as the characters begin to settle into the unfamiliar circumstances. This use of language, often too subtle to qualify as parody but too pronounced to be anything but deliberate, is in keeping with the larger theme announced in the first line of the novel: "This is the story of a sexual trauma". ${ }^{\mathrm{i}}$

Any revolution indicates the re-imagining of both individual and collective identity. Indeed, in the aftermath of a revolution, it may become difficult or impossible to distinguish between the two, as collective change creates a corresponding demand for a shift in individual self-assessment. Following the Cultural Revolution in China, for example, there was a need to recalibrate the language in order to effectively "... code new social facts, although old social norms can also be discerned in the new formulae, thus showing that social changes are built on a previous social order $^{\prime \prime i i}$. Because language is used universally, the societal shift is created and re-created every time one speaks, listens, writes or reads, particularly if there is political pressure to adopt changes. However, since the time of the French Revolution, socio-political dogma has also sought to place emphasis on the individual, providing him or her with new lenses and tools with which to view himself. In his introduction to a series of articles about the intersection of language and revolution, Halfin relates that in modern times: "... the question of the Self arose... A project of self-recreation had begun in earnest: New German, New Jew, New Man, New Woman..."iii.

The concept of a 'language of revolution' will be applied to Amis's The Pregnant Widow, in order to unpack and examine the author's intention behind the conceit. A close textual analysis and deciphering of the allusion and 
symbolism in the novel, coupled with an analysis of Amis' style of satire, will be used to support an interpretation of the overt and subtle messages of the work. In addition, views and interpretations of the sexual revolution, which form the socio-historical backdrop for the novel, will be examined and applied through the use of social criticism from secondand third-wave feminist scholarship.

\title{
3. Revolution and its Aftermath
}

The 'language of revolution' support changes in one's conception of the self or of society. Of course, these cannot occur universally at will. Rather, their adaptation inevitably takes time, and during this adjustment period things may seem new and strange. Within both historical non-fiction and fiction, we encounter a litany of 'rules' governing these shifts, letting both characters and readers know and absorb what has taken place. This is precisely what we can observe at the start of Amis's novel, and to a lesser extent throughout. Of course, here again, the author's skillful satire plays a role, presenting for our consideration a set of 'rules' or circumstances that appear bizarre until we stop and consider how familiar they actually are. Much is made, for example, of Lily's desire and ultimate failure to "act like a boy", an endeavor that apparently requires a certain type of distinctly female attire:

\begin{abstract}
Lily and Keith broke up because Lily wanted to act like a boy. That was the heart of the matter: girls acting like boys was in the air, and Lily wanted to try it out... Lily had her hair restyled, and bought lots of miniskirts and cut-off culottes and halter tops and see-through blouses and knee-length patent leather boots and hoop earrings and kohl eyeliner and all the other things you needed before you could act like a boy. And Keith just stayed the same. ${ }^{\text {iv }}$
\end{abstract}

By stating "girls acting like boys was in the air and Lily wanted to try it out", Amis lets us know of a disquieting, though attractive, shift in circumstances. It is immediately obvious, however, that not only a practice but a basic genderbased definition has been altered. Lest we assume that it is the female role that has become more malleable, however, Amis also makes it clear that a threat to the feminine is still in the process of being vanquished. The sexual revolution, presumably, has some role in this, though we are not yet sure how effective a role. The dust has not yet settled and it appears that people of both genders are confused and re-establishing their place. Violence may not be imminent, but is not far away either in terms of time or place. "I suppose drugging girls was your only hope - back then. That was how you did it", a character remarks; 'back then' - before the sexual revolution - already seems far-off ${ }^{\mathrm{v}}$. Without the new standard of licentiousness, it already seems difficult to conceptualize how one 'did it' - presumably, how one found a sexual partner.

Of course, the reference to 'drugging girls' is deliberately disturbing, suggesting sexual assault in an echo of an earlier discussion, during which an Italian cultural heroine is introduced: "Kidnap and rape, in Sicily, provided the alternative route to confetti and wedding bells. Franca Viola challenged this"vi . As we learn, it had been the law and custom in Sicily that girls who were raped marry their rapist, allowing him to escape prosecution. That state of affairs, however, is in the process of change thanks to Franca Viola, who “... didn't go to the church. She went to the police station in Palermo. And then it was national news. Incredible girl"vii. Contextualized within a discourse on the sexual revolution, Viola's action is magnified and politicized: "She changed everything. Now Milan and Turin are partly civilized. Rome is beginning to get better"viii. While the original premise of a girl's brave stand against oppressive tradition reads as factual with regard to one individual, the exaggeration of her accomplishment elevates it to political status. The figurative truth of the statement provides a bridge between the factual and the somewhat hyperbolic, and between the personal and political.

Having established the political connotations of the sexual revolution, Amis imbues the change of circumstances with a feeling of urgency and the implication that survival may depend on conformity to the new standards. The discussion of female beauty, for example, has a connotation of a high-stakes situation, even if we aren't sure precisely what those stakes may be. Lily says: "I'd give up some of my intelligence for a little more beauty - but girls aren't supposed to say that now"ix . The idea is expanded through an ensuing discussion:

Girls need looks even more now. You'll see... it's not just about what kind of husband you can pull... You're wrong. Looks matter even more ${ }^{\mathrm{x}}$.

Of course, the emphasis on looks has been established since the very start of the narrative, through the narrator's inclusion of a character's body measurements following mention of their names. This is a double entendre of sorts, as it confers on the individual a sort of alternative moniker or code name, the futuristic connotations of which evaporate as we quickly decipher the meaning of the numbers. The juxtaposition of the familiar and unfamiliar, of the realistic and hyperbolic, creates the impression of a brave new world in which a new set of rules must be learned and navigated.

A political revolution carries with it equal measures of danger and hope. It is a radical overturn of previous powers and circumstances, so that, in some cases, those on top are now on bottom, and vulnerable. A revolution opens possibilities for some, but endangers others who now find themselves on the wrong side of the law. The device highlights the seriousness of sexual politics. Indeed, from the start of the novel, intimations of danger abound, as Lily and Scheherazade, entering town, are "engulfed" by young men ${ }^{\mathrm{xi}}$. That this is more than mere admiration is established by Keith's desire to protect or rescue the young women, and by the stark statement: "They probably hate us out there too. 
But at least they want to fuck us"xii. That the nature of the hostility between the genders is taken for granted rather than analyzed strengthens the impression of an inevitable competition and antipathy.

All of these factors lead us to the consideration that Amis is actually asking us to think of the sexual revolution as a 'real' revolution, not a natural blossoming or liberation, but an overthrow of one set of values for another - a cultural revolution of sorts. This conclusion is relatively easy, but the real question is to what end the author does so. What does he want us to realize regarding the sexual revolution and the cultural changes of the 1960s and 70s? Perhaps the primary purpose is to destabilize and therefore have us question our existing assumptions, in recognition of the fact that, as the famous saying goes, history is written by the victors. There is considerable tendency on the part of any new regime to promote the idea of its own inevitability, God-given right, or right according to natural law. After all, ever since Freud, the awareness of repressed appetites and the dangers of repression have been widespread. What could be more natural than the gradual dispelling of those culturally imposed constraints, freeing the individual from the bonds of both patriarchy and archaic moral standards? Amis asks us to consider that such views exist as a result of a set of carefully orchestrated and therefore inevitably biased values.

Amis's narrator, in the present day looking back upon his past and the lifestyle he embraced during that summer in Italy, is in one sense an apostate or a devil's advocate, refusing to glorify the seemingly paradisiacal circumstances and remaining - just as the younger Keith seems fixated on the social mores of the past through his reading of literature. However, he is not necessarily a counter-revolutionary. Rather, I believe, he is looking for a critical examination of what has occurred so far so that the revolution may continue. Whereas the starting point is the representation of a shining era within an idyllic setting, pitfalls are identified almost immediately:

Here they were in the She Decade - but they were all of them in the cusp of Narcissus. They were not like their elders and they would not be like their youngers. Because she could remember how it was before: the lighter weight on the individual, when you lived your life more automatically... They were the first that ever burst into that silent sea, where the surface is a shield that burns like a mirror... ${ }^{\text {iii }}$

This short, dense passage captures the unique opportunity and challenges of Keith and his cohorts. The mention of Narcissus suggests the trap of self-involvement, while the description of the 'silent sea' creates a numinous scene of rebirth.

\section{Gender Trouble}

A suggested conflation between the sexual revolution and feminism or women's liberation is not unique to Amis's revisiting of the era, of course, but it is open to question, particularly in retrospect. Many scholars at the time accepted the idea that the sexual revolution profoundly changed society and the individual. In a paper presented at a Symposium on the Sexual Revolution sponsored by the New York Society of Clinical Psychologists in March 1969, Feldman calls it a "fundamental change in our way of life" by which "we have all already been affected, possibly much more than we realize"xiv . However, Feldman also suggests that a movement beyond conventional homosexual pairing and toward a kind of autonomy has been brought about by the change in society. He describes the shift as follows:

The manner in which the youngsters dance tells us something about them as sexual beings. They have moved away from sexual contact in the frame of a relationship, as exemplified in the 'couples dancing' which was male dominated, stylized and romantic. Now, each freely uses his body as he wishes to give himself pleasure ${ }^{\mathrm{xv}}$.

Feldman also refers to the "erosion of roles all around us"xvi , characterizing the era as one that has liberated the individual from the male-dominated and stylized ritual and sharply prescribed roles of an earlier time. However, in retrospect, the observation is more often that behavior is at odds with stated views ${ }^{\mathrm{xvii}}$.

Indeed, one of Amis's primary arguments is that the sexual revolution has failed to fulfill its implied goal of liberating women. In a recent interview in which he recalls the era, Amis states: "The first thing they should have done is hammer down that men and women would do 50/50 in the home... women don't have it all, they $d o$ it all". The novel, however, suggests inequalities and more pernicious dangers. In fact, Amis entangles the reader in the complexities of gender politics and in his portrayal of Keith, Lily and Scheherazade, their actions and their stated viewpoints. We are unsure, for example, whether Amis is subverting the notion of essentialism or confirming it with his descriptions of 'girls acting like boys'. Judith Butler in Gender Trouble: Feminism and the Subversion of Identity addresses the 'performability' of gender, pointing out that gender-based identity is always socially constructed rather than an essential characteristic of a person. The appropriating of gendered behaviors at will certainly suggests a repudiation of essentialism, but it also suggests that there are stable and definable characteristics demarcating male and female. The concept settles uneasily in a layer of irony that is soon over-plastered by others. Looks were more important now, as Lily and Amis's narrator state several times. Yet how can this be so, if antiquated social norms that kept women subjugated by the power of the male and of patriarchy have been overturned? 
If looks matter more now - and even if appearance is conceptualized as a source of social power, or a type of currency it may follow that the empowerment of women is still an unfulfilled promise. Authors writing around the time of the sexual revolution recognized this fact. Germaine Greer in The Female Eunuch, and Betty Friedan's The Feminine Mystique both endorse the view that the pressure to adopt a feminized, conventionally attractive appearance is a tool of subjugation. Freidan points out that the 'feminine mystique' that was promoted by media in the 1950 s and 60 s was largely the invention of men, and was planned and executed with a specific, coercive purpose in mind - to confine women within the domestic sphere. Greer argues that the co-opting of the female image alienates women from it. However, in the Foreword to the 1999 edition of the book, she cautions against orthodoxy in the rejection of conventionally feminizing elements. She states, for example, "Bras are a ludicrous invention...but if you make bralessness a rule, you're just subjecting yourself to yet another repression"xviii. Liberation may come only when prescribed or enforced standards cease to exist or to be followed, not when they are simply reversed.

In the early 1990s, Naomi Wolf's The Beauty Myth puts forward the idea that they tyranny of conventional feminine beauty is in fact a tool that has evolved in order to further women's subjugation in response to the strides that feminism has made. Although aspects of Wolf's argument resemble that of her predecessors, her thesis was new. She argues, in effect, not that the emphasis on feminine beauty is a remnant of patriarchal oppression, but that it is in fact a newly actualized tool in the arsenal - or, at least, a tool newly honed and sharpened, and ready to take on the task of imposing internalized limits on women. Michel Foucault talks about the concept of societal standards forming an internalized set of rules capable of controlling and shaping behavior. The brutality of these controls in turn suggests that the sexual revolution was indeed much more than a matter of liberation and opening. Any liberation carries with it the possibility if not the certainty - of a corresponding backlash of oppression. Thus, as Amis points out, we need to consider that the sexual revolution is or was perhaps a true, bloody, take-no-prisoners revolution, because to deny that is to ignore the devastating potential of sexual politics.

The language of revolution is used to soothe the spirit and promote stability after upheaval. By displacing us within a familiar reality Amis forces us to examine whether we have fallen prey to this language of revolution. This linguistic displacement is the tool he uses to take us over that threshold.

\section{The Thousand and One Nights}

Once there, what are we to discover? Through his structured tale and multifarious literary references, Amis suggests that storytelling - and retelling- has an unimpeachable function, in that it is capable not only of conveying nuanced meaning, but of holding it up to the light. For a start, Amis's use of the name Scheherazade naturally invokes The Arabian Nights. Just like Franca Viola, who made a stand against the sacrifice of girls to male lust and violence, the legendary Scheherazade was a liberation heroine herself, putting an end to the nightly killing of young women as a sacrifice to a king's power and distrust of the female. The original story carries with it ample evidence of patriarchal oppression, of course, including the notion that these young women's lives are expendable, forfeit to a king's whim or pleasure $^{\mathrm{xix}}$. In the traditional story, Scheherazade puts an end to this ultimate expression of female exploitation through cleverness, knowing that more than corporeal attraction is needed to make sure that she does not join in the fate of the young women who came before her. At the same time, of course, Scheherazade merely works within the system; she wastes no time attempting to revolutionize it. She does not openly question the right of the King to use young women as grist for the mill of his desire and revenge; she merely devises something that will stop the diabolical turning of that mill. It is effective at least in part because she does work within the system presented to her.

Famously, Scheherazade's stories are her salvation. Trapped in the throes of a male power she could not control or even plead with, the fabled Scheherazade does the only thing she can do, holding the king's interest after night. Failing to hold the interest of the male is the cardinal sin because it exposes the female to her greatest peril, and male violence is associated at least in some small part with ennui and lack of fulfillment. We might speculate, of course, as to what this male restlessness consists of and is caused by. It is such a stark contrast to that mainstay of society, the stable family unit and the determination that humans view themselves as socially, if not inherently, monogamous. The King's lust for variety in The Arabian Nights is of course hectic and dysfunctional, and extreme expression of heterosexual and patriarchal behavior that is malignant in its ability to threaten the social order and must therefore be corrected. In invoking Scheherazade, is Amis suggesting that the sexual revolution itself gave rise to a similar out-of-control and ultimately harmful capriciousness of desire? Or, since in the original story it is the King's cuckoldry that precipitates his murderous acts, is female promiscuity - spoken of in positive terms in the novel - actually a dangerous trap?

The storytelling of Scheherazade in The Arabian Nights is a tale of obligation and of powerlessness as much as of the woman's cleverness. The stories are perhaps just another song and dance, another spell to be woven. If his attention can be held the woman can have life. If not, then she will be destroyed. What is curious, of course, in Amis' story, is that Scheherazade does not play the role of her legendary namesake, but clearly represents an invitation on the part of the author to decipher the meaning of her presence in the narrative. Scheherazade tempts Keith with the most elementary of means - her physical presence, her availability, and the tension that is created by her presence and accessibility in the face of Keith's commitment to Lily. Her role in the novel is predictable enough within the context of its basic premise the licentious summer in the lives of these young people at the height of the sexual revolution. Yet she is clearly also a disturbing figure, for the protagonist if not for the reader; she is the source of Keith's sexual trauma, an experience that "...ruined him for twenty years". In an interview, Amis states with regard to the sexual revolution "it was quite necessary and a great thing - but sort of a trauma for everybody" - and this trauma or 'wound', as he also defines it, is embodied, at least in part, in the character of Scheherazade. 
Perhaps the similarity between Amis' Scheherazade and her legendary predecessor is that, in both stories, she represents an interruption in the customary way of doing things, and a divergence in a different direction - one which also constitutes for the male protagonist a confounding of his original intent. Yet there is something unsatisfying about that interpretation. It would lead us to view what happens in The Pregnant Widow as a mere reversal of the old tale desiring monogamy, Keith is confounded and outfoxed by the (ironically) rather mute figure of this new Scheherazade, a woman whose physical appearance and availability tell their own stories. The interpretation is not without validity, but it is unsatisfying because it fails to address an element central to both the original story and Amis's narrative - arguably, it is also one that characterizes the conventional conception of the sexual revolution itself. And that element, again, is the importance of stories and storytelling.

Meanwhile, throughout the narrative of his summer in Italy, we see Keith reading various classics of English literature, finding fault with them because of their lack of relevance to their present, rearranged circumstances. He reads and dismisses Clarissa as ridiculous or unrealistic because, as he remarks to Lily, "Clarissa's a nightmare.... it's taking him two thousand pages to fuck her"xx. The observation does not wholly discourage him, however, in what appears to be a search for something elusive and lost. During the summer, he also reads his way through Pride and Prejudice, Wuthering Heights, Jane Eyre, Vanity Fair and others.

When one considers the hidden desperation that must underlie the original Scheherazade's nightly telling of tales, one can sense a similar desperation in Keith's sequential reading, retelling and ultimate rejection of classic romantic stories from literature. A similar suspense is present - will there be enough in the stories to hold his interest so that a status quo can be maintained, and a crisis forestalled? Of course, in this case, the answer is no. Thus, Keith's seeking out of stories has a futility to it that dispels the cleverness of the original Scheherazade. In a sense, her role was to demonstrate to the king that a woman can be more than just a body. She holds the king at bay with her storytelling rather than with the seduction of her physical being. Were she regarded on the basis of her physical presence, her survival would be far from guaranteed because she is demonstrably replaceable. Once she is valued for her intellect and talent as a storyteller, she becomes a distinct individual and replacing her is no longer an option. Thus, she is able to survive. In his sequential reading of stories of the past, is Keith, as well, trying to stave off the replaceable and perishable qualities of the flesh, and finding, to his despair, that it is becoming harder and harder to do so? If that is the case, of course, we must find solace in the fact that he ultimately narrates his own story, giving the permanence of narrative structure to his search, and preserving the trauma within his story so that he it cannot be annihilated by it. In this sense we realize, too, that the original Scheherazade's task was symbolic as well as practical; storytelling not only staves off death for her, but offers a kind of immortality. Amis acknowledges this - indeed, seems to depend upon it - but also refers to the dangerous knowledge of the possible death of stories due to shifting social circumstances that may kill their relevance. Although Keith's analyses of classic literature are often amusing, they are, of course, also intended to be disturbing and indicative of his difficulty in orienting to new circumstances, and inability to return to the old. The novel itself offers relief because, somewhere in its unwieldy structure and melding of past and present, it is a meta-fictional structure large and complex enough to contain his experience. This success points out another way in which storytelling offers hope for stability in the face of change - its ability to evolve, in addition to its inherent immortality. After all, the continued interest and therefore the success of the stories of the original Scheherazade lay in her inventiveness - in the fact that she was continually wracking her brains to come up with them.

Is Keith's desire for a story that will hold his interest so that his own life can be saved, or is he more concerned for the fate of the girls, in the sense that the disturbing expendability of the sexual partner after the sexual revolution may somehow be halted? Does his own sense of victimization by the new sexual standards - so curious and even amusing, initially, as it flies in the face of what we think we know about the male desire for promiscuity - come from an empathy with his (and Amis's) sister, whom the author clearly regards as a true casualty of that societal shift? That in itself might be grounds for Keith's (Amis's) more complex longing for a quintessential Scheherazade. Much as young Keith physically desires the Scheherazade of his summer in Italy, he courts himself with stories, trying and failing to fulfill the lost archetype. Having somehow internalized the lesson of the legendary Scheherazade, he wants more than bodies although, of course, his concurrent lust for the physical and the ease with which that may now be fulfilled also traumatizes and injures his flailing sense of self. It is with a sense of halfhearted relief that we find, so late in the story, that the narrator is in fact the older Keith - relief because he has survived to tell a tale of his own, and halfhearted because we can see so clearly at a distance the unfulfilled aspirations of the younger Keith, and what he has lost by living on the other side of the line that the sexual revolution has drawn through social history.

The notion of the Scheherazade-style sequential storytelling has another, more oblique parallel within the story, and it is here, perhaps, that the most hopeful message lies. When one refers to a general historical commentary on the sexual revolution, what is most striking is the degree to which it is defined by a series of influential texts - texts which both capture the changing moral and social standards, and subsequently become agents of revolution by spreading the changing values. Key texts which are cited as agents of the sexual revolution typically include both literary works such as Fanny Hill and Lady Chatterley's Lover (as well as various other works by DH Lawrence), memoir conceptualized as narrative (for example, the works of Anais Nin and Henry Miller), and finally culminate in the 60s and 70s with nonfiction works promoting sexual education and openness, such as those of Kinsey and Masters and Johnson. As both agents and markers of social change, these books (and many others) show a consistent trajectory, starting with the challenging of boundaries met by censure and censorship and continuing on to the persistent overcoming of boundaries, and, finally, a frank openness with regard to sexual matters. If one were to personify the sexual revolution, it, too, might 
amount to a version of Scheherazade, weaving story after story in order to dispel resistance and finally change a paradigm.

Tangentially, it is also interesting to note that although the sexual revolution is primarily associated with the 1960s and $70 \mathrm{~s}$, according to some historians it was not the first but the second such revolution, the first having taken place in the 1920s when standards of social behavior and sexual relations were similarly relaxed. The conservativism of the postWWII era may have necessitated a further thrust of the revolution, but it is clear from its literary antecedents, too, that the beginning of the movement is rooted in the early twentieth century. Of course, Amis and his narrator have an awareness of this, the very place where they are staying having been frequented by DH Lawrence, for example, and leading us to question Keith's preoccupation with the literature of the pre-Lawrence era, when the works of the 'first' sexual revolution may have provided a more useful compass. Of course, if the objective is to produce a sense of futility and disconnection in Keith's literary searching, pre-twentieth century literature is more suitable for the task. Lawrence is treated by the author with a mixture of amusement and familiarity that brands him as a compatriot of sorts, albeit one facing different challenges from the other side of a historical divide. For example, the narrator states:

The police were always abnormally interested in DH Lawrence. It wasn't only Lady Chatterley that caught their attention: so did The Rainbow (Obscenity) and so did Women in Love (libel). And so did a very late book of verse (grossly indecent, according to the Home Secretary; nauseous and disgusting, according to the Director of Public Prosecutions). Sufficiently gay, deep down, to be thrown behind bars in the first place, Lawrence nonetheless ignored the ridicule of his friends and called this collection Pansies - a pun, he said, on pensees $^{x x i}$.

Yet Lawrence is vindicated even as fun is poked at him. The "abnormal interest" of the police is a transferred epithet of sorts, as the notion of abnormality may have been applied to Lawrence himself and his range of sexual interests during his historical era. Transferring this notion of abnormality to the police, however, has a dual purpose; it reflects what may be considered objective truth - which at the same time casts aspersions on the police themselves for their level of interest in what they would probably consider deviant literary preoccupations and lifestyle - and it sets the expectation and assumption that both narrator and reader are on the side of the historical divide that would consider the persecution of Lawrence, rather than Lawrence himself, 'abnormal'. The phrase "sufficiently gay, deep down, to be thrown behind bars" connotes a similar marker of changing standards. The statement is satirical in that it displaces an outmoded (but historically accurate) concept into the current time, in a matter-of-fact language that is discordant enough from current standards that it provokes an incredulous reaction from the reader. The moment of incredulity is closely followed by the realization that it would have been accurate within a certain historical period. The fact that we thus engage actively with the statement - grapple with it for a moment, as it were - gives it much more power than a statement that is more obviously contextualized within a past time. For example, if Amis had simply stated "During Lawrence's lifetime, homosexuality was a crime", chances are we would have glossed over the statement, given that it is common knowledge. Because Amis catches us off guard, however, we are forced to consider the concept of homosexuality as a crime with fresh eyes, and, hopefully, to overthrow it all over again. Thus we participate in a facet of revolution.

We cannot fail to notice that the treatment of Lawrence is gentler than that of Keith's assessment of earlier literature or of Amis's treatment of Keith. There is a perhaps grudging admiration, in the passage above, of Lawrence's boldness in choosing the title "Pansies" for his book. The mention of the official judgment on his books as 'obscene' or 'libelous' is not an argument for us to accept these judgments - rather it is part of the 'abnormality' of the legal persecution of Lawrence. There is a world of difference between the mildly humorous summary of Lawrence's work and Keith's fatuous comment regarding Clarissa. The latter shows a sharp dissonance between what Keith is reading and the time he lives in, offering little possibility for a meeting of the minds between the two. Keith's comment is ignorant, but there is no suggestion of redeeming features of Clarissa or its author. The gentler treatment of Lawrence suggests that he may indeed have something of value to say.

In his day, Lawrence argued for sexual openness and a loosening of tight moralistic standards but (despite abnormal prosecution by the police) did not suffer the confusion of a widespread social change shifting the relationship between men and women. Amis' comment that the sexual revolution was "quite necessary and a great thing"xxii is coherent with his implied acceptance of Lawrence's life and work; however, his refusal to accept the social changes unquestioningly highlights the difficulties that ensued following the shift - the fact that, in a sense, society has bungled and continues to bungle these admirable ideas. Hence the continued need for storytelling. Scheherazade's task is still incomplete; the survival and thriving of the female (and male) is still not assured. Storytelling itself is nowhere near as easy as Scheherazade made it seem, but Amis's narrator demonstrates his willingness to try his best.

In examining the rift that a revolution leaves in society as well as the crumbling ground on either side of it, completing the aims of the revolution and rectifying its liabilities becomes possible, though never, of course, assured. A textual analysis of The Pregnant Widow, its use of satire and the language of revolution, and its social antecedents uncovers the real work that Amis is doing in this regard. The symbolism of the title motif, the pregnant widow, suggests the impossibility of a seamless transition between one era and another; by the time the 'widow's child is born, it progenitor is dead and buried if not forgotten. That unborn child embodies the past in the future while the widow herself is the bridge between the two, with the arduous prospect of birth standing between the present and that eventual outcome. Amis's novel captures the transient moment while seeking to transcend it. 


\section{References}

Amis, M. (2010). The Pregnant Widow. Toronto: Alfred A. Knopf.

Butler, J. (1990). Gender Trouble: Feminism and the Subversion of Identity. New York: Routledge.

Feldman, E. (1969). “The Sexual Revolution”. Journal of Contemporary Psychotherapy 2 (1), 54 - 56.

Foucault, M. (1976, 1979). The History of Sexuality Volume 1: An Introduction. Translated by Robert Hurley. London: Allen Lane.

Friedan, B. (2013). The Feminine Mystique (50th Anniversary Edition). W.W. Norton \& Company.

Ghosh, M. (2005). "When Dreams travel: "Writing Back" to the Arabian Nights". In Kundo, Rama. Studies In Women Writers In English Volume 2. Atlantic Publishers \& Distributors.

Greer, G. (2009). The Female Eunuch. New York: HarperCollins.

Halfin, I. (2002). Introduction, Language and Revolution: Making Modern Political Identities. Cummings Center Series. New York: Routledge.

Martin Amis The Pregnant Widow (Interview). Youtube. Available: www.youtube.com/watch?v=rqSNj7UmOs0

McLean, K. (2004). "Negotiating (Non)Monogamy: Bisexuality and Intimate Relationships". Journal of Bisexuality 4(1-2), $83-97$.

Robinson, I. E. and Jedlick, D. (1982). "Change in Sexual Attitudes and Behavior of College Students from 1965 to 1980: A Research Note". Journal of Marriage and Family 44(1), 237-240.

Robinson, V. (1997). "My baby just cares for me: Feminism, heterosexuality and non monogamy". Journal of Gender Studies 6(2), 143-157.

Smith, T. W. (1990). “A Report: The Sexual Revolution?” The Public Opinion Quarterly 54(3), 415-435.

Treas, J. (2002) "How Cohorts, Education, and Ideology Shaped a new Sexual Revolution on American Attitudes Toward Nonmarital Sex, 1972-1998”. Sociological Perspectives 45(3), 267-283.

Wolf, N. (2009). The Beauty Myth. New York: HarperCollins.

Yuan, J.F; Kuiper, K., and Shaogu, S. (1990). "Language and revolution: Formulae of the Cultural Revolution". Language in Society 19 (1): 61- 79.

\section{Notes:}

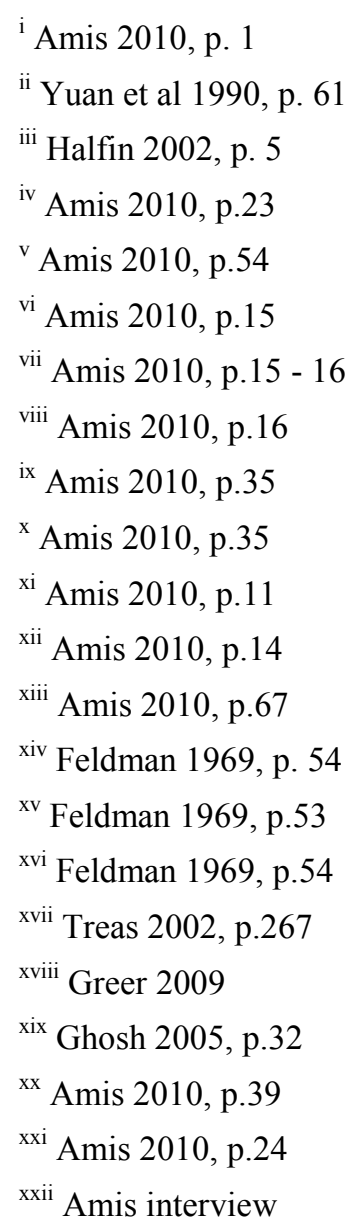

